体奇の学漗評価に関する管理学的研究

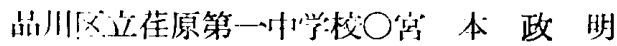

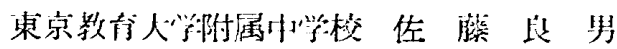

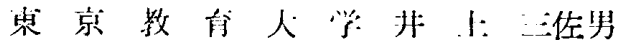

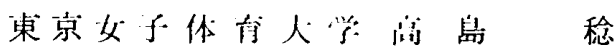

1. 研究のをらい休奇の学習評価に戌する龹践的 碎究は，きわめて充㓳していと考えられるが，一般们 には，資料の整理と解釈のしかたに重点が和かれ，学習

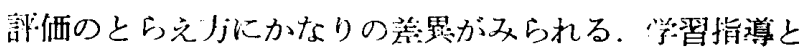
管理をめぐつて，“等留評洒の構暹之手順などについて，

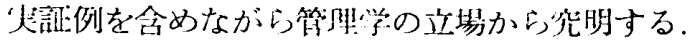

2. 研究の進め方協同討議を通して学習誂価の上 らえ方，考え力，手順について考えると共に，陸上競 抆, バスケットボール, バレーボール, 剣道の 4 種日を 選び，拣際の評価活動として可能かを奏証する。

3. 学㕷泙佂の考え方一般的には，学習評価之 は，単に学習の效果き紹思を評価するといつたものだけ

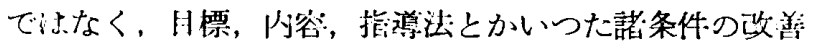
に役立てるもので，学妝がより效䱊的になるようにナ゙口 七スについての哈昧も含めた広い内谷がある。

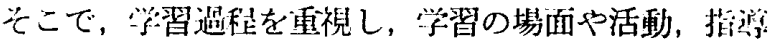

がどうであつたかを確かめ，学習過程へのコントロール が必要と桨えその乎順を考えた。

\section{4. 学習評価の手.頂}

(1) 学習内容の分折ととらえ方（A票）

○拔術の構造を朝らかにして扰く。

○ルール，マナー，健康・安全との結びつきを考え る.

(2) 評価計画の作成 $(\mathrm{B} \cdot \mathrm{C}$ 票)

○評価段階を明らかにしておく。

○収集方法を具体似にする。

(3) 評価活動

○指尊計画で具体似にしておく（D票）

○达祭の記録（走と幅とび）

\section{5. 今後の課通}

(1) 学習内空つ分折のしかた

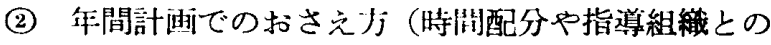
閌題)

(3) 学溜形態との罚係

(4) 整理と活川

（5）マナー，健康・努企の段階と挍術との絬びつき

\section{体育における学琶管理の研究}

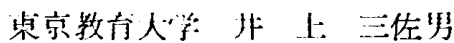

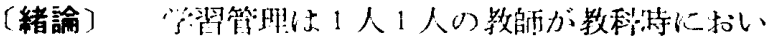

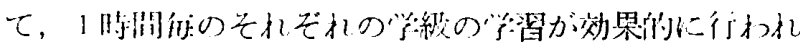

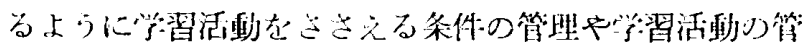
䧉をちることが主となるので，LM の人きな䦌題である

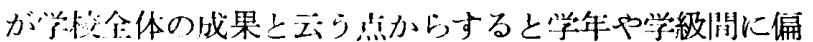
よりがあつては具命が琹いわけである。従つてそのよう に学級閂に差ができないように，教師の間の調整や教師 への指高，援助が必要であるということで $\mathrm{MM}$ や TM からも睊題にしなければならない。

ここでは LM の開題を主にし，学習活動をささえる 条件の内の学習計画と学習集団をとりあげ，それらが用 意されたときと，そうでないときとで学習成果につなが る伴徒の身体活動が 1 時限の授業从でどういう割合で現 われる傾问にあるかを探つて見ることにした．

〔方法〕都队中受校 2 校, 埼玉県 1 校を訪問し WFC 主伐つて授業を観祭し，その後指導者に質問した。更に 体育主任汇面接し 体育程営調查票による調査を行なつ
た。な打同じう法で 38 年に東京教育大学体育管理学研

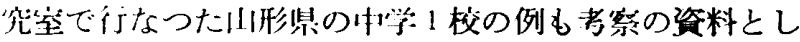
たＹ兴兴がそいである。

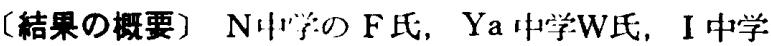
S氏は璡別にして，小集闭を設五したわけであるが，学 習計画を尘徒に持たせず，1时限の生徒の身体活動の割 合はそれぞれ，77.8\%，75.6\%，78\%，I中学H氏は一 斉指導で学習計禺なし，割合は $58 \%$ で最低。S中学O 代，Ya 学 Oi 氏は小集団設定，学習計画ありでそれ ぞれ 83.9\%，78\%で㷙述した人達より身体活動が多い 做响を示した。

体寺程営調睢の絬果ではS中学がもつともよく，評価 3，他は 2 であつた。

\section{〔問題点と今後の課䫄〕}

1. 資料数が少なく，性別や単元内時数もまちまち であつた

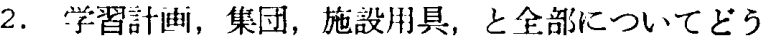
するか，また学習成果につながるものとして自主性や正 しさなどをとらえる工夫をすること。 